Hanan S. Shalaby and Hanan El-Sayed

\title{
Conceivable Effect of feeding Crackers Containing Peas and Tangerine Peels on Rats with diabetes induced by alloxan
}

\section{Hanan S. Shalaby and Hanan El-Sayed}

Food Science Department, (Rural Home Economic), Faculty of Agriculture, Zagazig University 44159, Egypt,

Corresponding authors: Email: Shalaby hanan31@yahoo.com.

\section{ABSTRACT}

$V$

egetable and fruit peels are commonly rich in phenolic with antioxidant properties so it considered metabolic syndrome remedies. This study was evaluated the phenolic compounds of peas and tangerine peels powder may as beneficial health on diabetic rats were fed on crackers enrich with $10 \%$ from its. The chemical composition of crackers was determined. Thirty healthy adult male albino rats were separated into five groups (six rats each) as follows: Group (1) were fed on basal diet as negative control. Other groups were injected subcutaneous with Alloxan (150 mg/kg body weight) to induce diabetes. Group (2), received the normal diet as a positive control, Group (3) intake standard diet and crackers without peels. Groups (4 and 5) fed on natural diet and cracker with 10\% peas and tangerine peels respectively for 8 weeks. In addition, glucose, lipid profile, liver and kidney functions were determined in serum and examination tissues were carried out. Results obtained that tangerine peels had the highest antioxidant activity and phenolic compounds. Pea's peels were the highest value of protein and fiber while fat and moisture contents is the lowest. Enrichment of crackers with $10 \%$ tangerine and pea's peels caused increases in sensory evaluation. Cracker with tangerine and peas peels showed improve glucose, serum lipid profile, liver, kidney functions. Pancreas tissues of groups $(4,5)$ were ameliorate compare with group (3). Thus, the study imagery those crackers containing $10 \%$ peas and tangerine peels exhibit high potential to enhance the nutritional value and protection against diabetes diseases.

Key words: Phenolic compounds, liver, kidney functions, diabetic rats. 


\section{INTRODUCTION}

Functional foods' are described as nutrients by addition, which gives positive effects on biological metabolic activities by improving general state of health (Rodríguez et al., 2006).

Pea has been widely consumed as a legume or vegetable throughout the world for satisfying the purpose of both human consumption and animal feeding (Garg, 2015). Various literatures also reported that peapods or peel obtained from mature fresh green peas have remarkable amount of dietary fiber, protein and calcium as compared to broad bean pod and okra byproducts. Biscuits have been reported to be prepared with $20 \%$ peapod powder, which was highly acceptable (Garg, 2015). Literature also suggested that cake with $5 \%$ of pea pod flour is highly admissible and can avoid the addition of synthetic color as it gives natural green pistachio color (Fendri et al., 2016).
In recent times, peapod fortified foods are considered to be functional foods as they contain a decent amount of fibers and essential minerals. Pea pods have proteindenaturing property that shows anti-cholinesterase activity and anti-inflammatory effect and because of strong anti-diabetic properties of pea, it shows shielding effects against various disorders like reproductive damages and renal issues (Mejri et al., 2019). Thus, it enhances enzymatic antioxidant activity, anti-inflammatory effects and inhibit lipid peroxidation, which shows a positive effect on health (Mejri et al., 2019; Zhang et al., 2020).

Studies were carried out on the functional properties of tangerine byproducts specially peel (Shafiya et al., 2018). Tangerine peel considered an excellent basis of pectin, Terpstra et al., (2002). Tangerine peels have dietary fiber that is bioactive compounds had antioxidant properties, which play role of 
Hanan S. Shalaby and Hanan El-Sayed

health advancing effects (Amr, 2011). Tangerine peels are rich in flavonoids $( \pm 122.5 \mathrm{mg} / \mathrm{g})$ with antioxidant properties and therapeutic importance (Wang Fu et al., 2019). Studies have description that bioactive complexes for tangerine peels increasing compare with pulp and seeds (Manners and Limonoids, 2007).

Crackers are commonly consumed between all ages because of nutritional value (Herath et al., 2018)

Diabetes is a various chronic metabolic confusion that influence really on the healthiness (Hogan et al., 2003). Diabetes is due to either the pancreas not producing enough insulin, or the cells of the body not responding properly to the insulin produced (Shoback and Gardner, 2011). As of 2019, an estimated 463 million people had diabetes worldwide ( $8.8 \%$ of the adult population), with type 2 diabetes making up about $90 \%$ of the cases (IDF, 2019) Rates are similar in women and men (Vos et al., 2012). Trends suggest that rates will continue to rise (IDF,
2019). In 2019, diabetes

resulted in approximately 4.2 million deaths (IDF, 2019). It is the 7 th leading cause of death globally (CDCP, 2020).

The aim of this study investigates of phenolic compounds, antioxidant activity of tangerine and peas peels extracts, and effects feeding of crackers add it on diabetic rats.

\section{MATERIALS AND METHODS}

\section{Materials:}

Peas (Pisum sativm) and tangerine peels (citrus reticulate) were obtained from local marketplace (Zagazig, Egypt) and washed and air dried in a ventilated oven at $40^{\circ} \mathrm{C}$ for $48 \mathrm{~h}$ and ground to a fine powder. Alloxan monohydrate and all kits were purchased form Sigma-Aldrich (MO, USA).

\section{Methods:}

Pea and Tangerine peels extracts were prepared according to Shiban et al., (2012), as follow: $10 \mathrm{~g}$ of pea or tangerine peels powder were separately blended for $2 \mathrm{~min}$ 
Hanan S. Shalaby and Hanan El-Sayed

with $600 \mathrm{ml}$ of $80 \%$ ethanol.

The mixture was then left, in the dark; at room temperatures for $4 \mathrm{~h}$ prior to filtration (Whatman No. 1) and centrifuged at $3500 \mathrm{rpm}$ for 10 min. Extracts were kept at $-20^{\circ}$ $\mathrm{C}$ until analysis.

\section{Concentration of total phenolics (TPC):}

The measurements of overall phenolic compounds (TPC) in peas and tangerine peels by Folin-Ciocalteu reagent as reported by Skerget et al. (2005), Total phenolic contents, were expressed as Gallic Acid Equivalent (GAE), per mg extract.

\section{Radical scavenging activity} (RSA) of peels

Radical scavenging activity of peel extracts against DPPH were determined according to Hanato et al. (1988) and Gulcin et al., 2004). Peas or tangerine peels (10 mg extract/10 mL solvent) added to $3 \mathrm{~mL}$ of $0.1 \mathrm{mM} \mathrm{DPPH}$ ethanol and incubated for 60 min at room temperature. The measurements of the absorbance at $517 \mathrm{~nm}$ was performed. Percentage of antioxidant activity of DPPH collated following:

DPPH scavenging effect $(\%)=$ $\left[\left(\mathrm{A}_{0}-\mathrm{A}_{1}\right) / \mathrm{A}_{0}\right] \times 100$.

Where, $A_{0}$ is the absorbance of the control reaction and $A_{1}$ is the absorbance in the peas or tangerine peels.

Chemical composition of crackers and peels powder

Moisture, crude protein, fat, ash and total dietary fibre, contents of peas or tangerine peels powder and crackers were determined by the standard procedures AOAC (2010). Total carbohydrates were determined according to the equation:

Total carbohydrates $=100$ - (crude protein $\%+$ crude fat $\%+\operatorname{ash} \%+$ total crude dietary fibre \%).

\section{Crackers preparation}

Crackers preparation was prepared according to the method explained by Ahmed and Abozed (2014) with some modifications using $100 \mathrm{~g}$ wheat flour with $2 \mathrm{~g}$ salt, $2 \mathrm{~g}$ sugar, $5 \mathrm{~mL}$ sunflower oil, 
Hanan S. Shalaby and Hanan El-Sayed

packing powder $(0.2 \mathrm{~g})$, yeast $(2 \mathrm{~g})$ and water $(40-60 \%)$. The dough was mixed for 3-4 min in a Hobart mixer, at $\left(25^{\circ} \mathrm{C}\right)$. The control samples (C) was without peels, while the other samples were adding 5\% and $10 \%$ peas peels respectively and named of treatment (1) and treatment (2). In addition, treatment (3) and treatment (4) were adding to contained $5 \%$ and $10 \%$ tangerine peels respectively.

The crackers were cut into slices to small round pieces or stars and flattened for $10 \mathrm{sec}$ using manual equipment then put into metal dishes and baking an oven for $10 \mathrm{~min}$ at $160^{\circ} \mathrm{C}$. The crackers were allowed to cool after baking covered with foil and stored at $4^{\circ} \mathrm{C}$.

\section{Sensory evaluation}

Organoleptic properties of crackers samples were examined according to Wanyo et al. (2009). Crackers offered in a conserved pocket coded with special numbers to eight panelists who were invited to pace their sensory quality.
Crackers were organoleptically evaluated for sensory characteristics of different samples of crackers for different characteristics as (10) for all: odor, color, appearance, taste, crispness, and overall acceptability.

\section{Induction of diabetes}

Diabetes was induced using Alloxan (150 mg/kg body weight) in disinfected normal saline (Jelodar et al., 2010). Diabetic rats have reserved for the after $24 \mathrm{~h}$. on $5 \%$ glucose solution to stop hypoglycemia after the injection drug (Balasubramaian et al., 2004), next two days measured glucose levels of fasting blood with alloxan, after 4-h. was 295 $\mathrm{mg} / \mathrm{dL}$. The blood samples were collected from the tail rats (Aslan et al., 2007a, b). The blood samples have been collected after 6 weeks feeding and analysed.

\section{Biological experiment:}

Albino rats (Sprague Dawley strain) were reserved in animal house at an ambient temperature of $20-25^{\circ} \mathrm{C}$ and 
Hanan S. Shalaby and Hanan El-Sayed

50-55\% relative dampness with $12 \mathrm{~h}$ dark and light series. Animals were Fed on basal diet and water ad libitum for 2 weeks as adaptation period. The basal diet prepared according to Reeves et al., (1993). The trial procedure was accepted in Department of Animals, Faculty of Agriculture, Zagazig University, (Egypt).

Thirty healthy adult male albino rats were separated into five groups (six rats each) of equal weight as follows: Group (1) were fed on basal diet only as normal control rats (negative control). Group (2), diabetic rats (positive control) received the basal diet only. Group (3) as a diabetes intake on crackers without peels. Diabetic groups (4 and 5) taken crackers with $10 \%$ pea's peels and $10 \%$ tangerine peels respectively for 6 weeks.

\section{Biochemical analysis of serum}

Blood samples were collected by $5 \mathrm{~mL}$ syringe by cardiac pierce after fasting the rats through the night. Determined of serum triglyceride, total cholesterol,
HDL-C levels according to Devi and Sharma, (2004). LDL $-\mathrm{C}$ was analyzed following the method of Johnson et al., (1997). Liver enzymes, Alanine Amino Transferase (ALT), Aspartate Amino Transferase (AST) and total serum protein using Kits (Young, 2001). Kidney function was estimated as serum creatinine and blood urea nitrogen by enzymatic methods using commercial kits from Sigma-Aldrich (Young 2001).

\section{Tissue examination}

Specimens from pancreatic, liver and renal tissues were collected after scarification of experimental rats, collected tissues were fixed in $10 \%$ buffered formalin for $48 \mathrm{~h}$. Five microns thin sections were prepared and stained with Hematoxylin and Eosin and examined according to Suvarna, et.al., (2013).

\section{Statistical analyses}

Statistical accepted of according to the method explained by Steel and Torrie, 
Hanan S. Shalaby and Hanan El-Sayed

(1980). The levels of markers were analyzed by least significant difference (LSD). Means with different superscript letters for the same analysis are significantly different at $p \leq 0.05$ and nonsignificant $\mathrm{P}>0.05$ : means with the same letters.

\section{RESULTS AND DISCUSSION}

Results of total phenol contents (TPC), flavonoids and radical scavenging activity assays are presented in Table (1). The data showed that citrus peels powder extract $(\mathrm{Cr})$ had the higher total phenols being, flavonoids and radical scavenging activity (RSA) than peas peels powder extract (Ps). Mohamed and Fayed, (2020), exposed that phyto compounds had a role of the natural antioxidant. Moure et al., (2001) who description the antioxidant components utilized for rising the stability of food and stopped lipid per oxidation and used for defensive oxidative harm during the life method using of scavenging oxygen radicals.

Previous studies Luo et al., (2019), have indicated that flavonoid content of tangerine peels was reaching $122.5 \mathrm{mg} / \mathrm{g}$. Abd-Alla et al., (2016), estimated total phenolic acids for peas pod powder as 121.43 $\mathrm{mg} / 100 \mathrm{~g} . \quad$ Li et al., (2018), indicated that tangerine peel could be a high of bioactive compounds containing of natural antioxidants such as phenolic acids. Shafiya et al., (2018), reported that main bioactive components had health benefits are photochemical such as phenolics in fruits and vegetables especially the tangerine flavonoids containing of anticancer, antiviral and anti-inflammatory activities. Wang et al., (2014) showed tangerine peels had the total flavones comparing with edible parts of the fruit.

Chemical composition of peels powder and crackers products are presented in Table (2). The chemical analysis appeared that the highest content of moisture was crackers products containing of $10 \%$ tangerine or peas. While control crackers (C) had the reduced moisture, content $(13.80 \%)$ compared with 
Hanan S. Shalaby and Hanan El-Sayed

crackers containing peels

powder.

The highest protein content was registered in crackers products containing $10 \%$ peas peels powder (T4) comparing to the other crackers products. The protein content of crackers containing additives (Ps and $\mathrm{Cr}$ ) increased by increasing the amount additional. According to fat content, the highest value was in tangerine peels powder. The lowest value was $0.65 \%$ in peas peels powder. These results are similar to findings Abd-Alla $\boldsymbol{e t}$ al., (2016) included that peas peel's carbohydrate and protein content were 54.60 and $17.33 \%$ respectively. Protein content was not near to Belghith et al., (2016) which registered that its value was $6.73 \%$ in pea pod peel powder.

As shown in Table (2), the tangerine peels $(\mathrm{Cr})$ and tangerine crackers products (T3, T4) had the highest ash content. These variation proteins, ash may be due to frying technique, and varietal change of percent fiber. Authors Kamal et al., (2016), described similar results.
Crackers have small sugar, modest rate of fat and comparatively little rates of salt (Han et al., 2010). In addition, results demonstrated that the crackers containing peas peels had high the fiber content (T1 and T2) comparing with control crackers (C). Elleuch $\boldsymbol{e t}$ al., (2011), included that a little fermentable hemicellulose fiber; raise fecal mass through high fecal flora by difference of much fermentable fibers, such as pectin.

Crackers benefits as a basis of 1 different additional nutritionally that source of rich components for the various products as a good snack (Sudha et al. 2007).

The total carbohydrates of crackers control (C) had the highly percentage $(69.32 \%)$ compare with others crackers products. It was noticed that with more peels powder added to crackers decreased in carbohydrates values. These results agree with Waheby, (2018).

Table (2) presented the highest fiber was found and the lowest fat and moisture contents in peas peels, 
Hanan S. Shalaby and Hanan El-Sayed

comparative with in all samples tangerine crackers. While crackers peas (T2) has, the highest of fiber was in comparative with others crackers products. These results of the present work agree with Meenakshi, (2015), designated that the raise of peas pod powder created therefore utilized like a potential dietary fiber addition in crackers.

The organoleptic properties of crackers products are shown in table (3). Sensory test was in significant differences in color, texture and appearance of crackers products of all treatments. Increasing crackers $10 \%$ tangerine and peas peels (T2, T4) caused increases in panelist scores. The samples revealed that crackers containing $10 \%$ tangerine peels had the highest preferred scores all. Concerning the score of color, appearance and taste, it could be noticed that crackers containing $10 \%$ peas peels(T2) that there was lower score compared with all samples. However, crackers containing $5 \%$, and $10 \%$ tangerine peels
(T3, T4) showed higher score for color, appearance and taste. The results indicated that the level of increased peas and tangerine peels in crackers increasing of hardness, or breaking. These results agree with O'Shea et al. (2017). The increasing of dietary fiber in crackers could be demean texture and crispness is of particular importance when making crackers (Dokic et $\boldsymbol{a l}$. 2015).

The plant as a source of food and can be consumption as a health product is rising of healthy people (Matheka et al., 2011). From table (4), it can be noticed that the levels of blood glucose was increased with significant different $(\mathrm{p}<0.05)$ in all groups diabetic rats as compare with the normal control at the beginning of period study. The rats fed cracker-containing tangerine and peas peels (155.973, $215.25 \mathrm{mg} / \mathrm{dl}$ respectively) were described during decreasing significantly blood glucose comparing to positive group. These decreases could be due to raise dietary fiber in crackers. These results agree 
Hanan S. Shalaby and Hanan El-Sayed

with Amr, (2011), showed that tangerine peels mixture at different levels caused different significant $(\mathrm{p}<0.05)$ decreased in levels of blood glucose.. Decreasing blood glucose by increasing dietary fiber intake (Lafrance $\boldsymbol{e t}$ al., 1998 and Sry et al., 2019)). In addition, flavonoids decreasing blood glucose (Miyake, et al., 1998).

Table (5), it might be examined that positive group of diabetic rats $(\mathrm{G} 2)$ was increase in T.C, TG, LDL and VLDL cholesterol as compared to negative group and all other groups. On the other hand, it can be showed that the other groups of rats fed on crackers $10 \%$ tangerine and peas peels (G4, G5) showed lowing of blood lipid profile and the highest significantly rate of HDL cholesterol. Also, HDLcholesterol was significantly improved increase in rats fed on crackers $10 \%$ tangerine and peas peels (G4, G5) groups comparing to positive group $(p<0.05)$. These results are in according to person's description by Amr, (2011). In addition, Figuerola et al.,
(2005), showed that eating dietary fiber had encourage physiological roles such as decreasing blood triglycerides and glucose. Also, acting a significant function in the avoidance diseases such as obesity and diabetes disease. The increasing of dietary fiber intake decreasing plasma lipids in hyperlipidemia persons (Lafrance et al., 1998). Dietary peels contained of main bioactive compounds, especially phenolics identified for health benefits that included free radical scavenging activities (Shafiya et al., 2018). Tangerine peels improved lipid profile in diabetic rats that contained phenolic and flavonoid compounds, which had antioxidant properties (Amr, 2011). Phytophenols give efficient profits for stopping and preventing free radicalmediated diseases such as cancer (Huang et al., 2005), diabetes (Boynes, 1991), Tangerine fiber can be using for decrease of remaining nitrite values (FernandezGines et al., 2003). Tangerine peel also advances 
Hanan S. Shalaby and Hanan El-Sayed

physiological roles have decrease in blood cholesterol value and glucose attenuation (Figuerola et al., 2005). Various epidemiological searches can be recognized the efficiency of tangerine peel in decreasing the serum triglyceride value, serum total cholesterol, liver total lipids, and liver cholesterol (Terpstra et al., 2002). The present data agree with Chiba et al., (2003) and Miyake, et al (1998), those established that flavonoids lowed the total cholesterol and triacglycerols in the serum blood and tangerine phenolic and flavonoid compounds shows biological and pharmacological possessions such as anti-inflammatory, anti-carcinogenic and lipid decreasing activities. These results with agree with Julius et al.., (2008), exposed that tangerine peels caused significant lower of total values of cholesterol, triglycerides and blood pressure after 4 and 8 weeks of treatment comparing to baseline of patient. It contains bioflavonoid, includes polymethoxylated flavones, which had useful effects on lipid values because of glucose tolerance.

Effect of crackers products on liver functions rats (ALT, AST, and T.P) is presented in table (6). It could be concluded that the group rats fed crackers products containing $10 \%$ tangerine and peas peels were illustrated by the highest significantly of total protein comparing to the positive group of diabetic rats. These raising because of high protein contents of crackers products containing peels. Also, results demonstrated of positive group diabetic rats proved significant high in liver enzymes (ALT, AST) compare with crackers products containing $10 \%$ tangerine and peas peels $(\mathrm{G} 4, \mathrm{G} 5)$ groups that was decreased. Crackers products containing $10 \%$ tangerine and peas peels (G4, G5) have many of bioactive agent as polyphenols. The best groups was crackers products $10 \%$ tangerine (G5) which are decreasing levels of ALT, AST. The feeding rats on crackers products $10 \%$ tangerine and peas peels stopped the increase of mean 
Hanan S. Shalaby and Hanan El-Sayed

ALT, and activities as containing of phenolic and flavonoid compounds. These results are according to previous researches, AnaAngelica et al., (2009), who showed that activities of AST, ALT have the highest in the serum of diabetic animals. These results agree with Eliza, et al., (2009), appeared that levels in total AST, ALP, ALT, were lowering by antioxidant avoid oxidative stress and defend liver function.

As shown in table (7), feeding of the diabetic rats with crackers products containing $10 \%$ tangerine and peas peels (G4, G5) prevented the rise of significant serum creatinine and urea concentrations. The levels of avoidance are increased with crackers products $10 \%$ tangerine (G5). The value of decreasing in the kidney function parameters were recorded $0.710, \quad 0.700$ $(\mathrm{mg} / \mathrm{dl})$ for creatinine and $62.813,53.623(\mathrm{mg} / \mathrm{dl})$ for urea at the end experimented with crackers products $10 \%$ tangerine and peas peels (G4, G5) respectively. Although the low values was negative and positive control groups in the kidney function parameters compared to all crackers products. Where, Verma and Bordia, (1998) showed that rise kidney functions are signs of kidney dysfunctions in the diabetic disease compared to control. These results agree with Jarald et al., (2008), who indicated that all diabetic rats are a significant high in creatinine and urea values comparing with group normal rats. Kidney dysfunctions in the diabetic rats have the generation of reactive oxygen species and lipid peroxidation are tissue damage following ischemic insult. The raise of production of free radicals because oxidative stress could be unfavorable property commonly seen in diabetes similar to nephropathy disorders (Hamden, et al., 2008). The perfection in kidney function of diabetic rats with feeding different values tangerine peels may be connected to its antioxidant properties, and had scavenge free radicals, specially superoxide anions and thereby 
Hanan S. Shalaby and Hanan El-Sayed

may defend cells from oxidative stress (Amr, 2011).

\section{Histological examination}

The humanizing effects of diabetic groups rats fed on crackers products $10 \%$ tangerine and peas peels were established by histopathological assessment of the pancreas, liver and kidney are exposed in photo. $(1,2,3)$

\section{Pancreas sections}

Photo (1.a) shows
sections from pancreas of
negative control group (G1),
revealed normality in both
exocrine and endocrine
counterparties with a healthy
acinar epithelium and its
secretary granules. While in Photo. (1.b), positive control group (G2), indicated serial sections from pancreas of rats of this group revealed characteristic changes represented by lowing thickness of the islets cells, degenerative effect in the beta cells of the islets, mostly cloudy swelling and hydropic degenerations. Necrotic and apoptotic changes modest numbers of beta cells were a pathognomonic lesion, the necrotic cells completely or partly missing their nuclear and or the cytoplasmic structures, sometimes with a ballooning changes in affected cells. Apoptotic cells were small, with shrunken deep eosinophilic cytoplasm and a small nucleus. On the other hand, the glucagon secreting cells (alpha cells) and the somatostatin secreting (delta cells) were apparently normal, no changes could by detected in any of them. The exocrine pancreas demonstrated slight cystic dilatation and fibrosis of the affected ducts and congestion of several pancreatic blood vessels. On the observed, also Photo (1.c), group fed on crackers without any additives (G3), serial sections from pancreas denoted pancreatic islets that regained their normal sizes, distribution and cellular morphology, not all, but most of them. However some of the islets cells particularly beta ( $\beta$ - cells) and a few alpha cells ( $\boldsymbol{\alpha}$-cells) showed mild to modest degenerative changes, mostly hydropic degeneration more- 
Hanan S. Shalaby and Hanan El-Sayed

over a few $\beta$ - cells revealed early apoptotic and or necrotic changes. Some exocrine ducts were cystically dilated. While Photo (1.d), pancreatic changes in this group were mild and promising, where the islets of Langerhans were comparatively larger with activated beta cells and alpha cells. A few beta cells suffered degenerative mainly cloudy swelling and hydropic degeneration and early necrotic changes .The exocrine pancreas was almost normal. In addition, Photo (1.e), serial sections from pancreas of this group pointed out apparently normal endocrine islets cells with regard to densities, distribution, size, and cell populations. The Beta and alpha cells were healthy and apparently functioning in most parts of the islets. The exocrine pancreas is also in a good histomorphologic architecture. In some sections, a very view number of beta cells showed hydropic degeneration. This results agree with Kirtikar and Basu (1988), who reported that alloxan produce hyperglycemia by selective cytotoxic effect on pancreatic beta cells and increase oxidative stress and Lenzen $\boldsymbol{e t}$ al., (1988) showed that damages the insulin producing pancreatic $\beta$-cell resultant in a decline in endogenous insulin liberate in examination of pancreas sections.

\section{Liver sections}

Liver tissues of rats in control normal group (G1) of Photo (2.a), showed preserved hepatic cords, portal triad's structures, vascular tributaries, biliary system. Von kupffer's cells and supporting stroma .Photo (2.b) liver sections positive control group (G2) revealed characteristic biliary proliferative reactions, which extend to the interlobular tissue is at a variable distance with a bile stasis particularly around the portal area consequently suspected raising in alkaline phosphatas is expected. Multifocal areas of early hepato-cellular necrosis were seen and represented by pyknotic nuclei and deep eosinophilic cytoplasm, cojoined with moderate hepatocellular degenerative effects of 
Hanan S. Shalaby and Hanan El-Sayed

changeable amounts with overcast swelling, hydropic deterioration, vacillations and signet-ring fatty different cells. A speculated raising in hepatic enzymes is suspected. Scattered multifocal apoptosis of individual hepatocytes was seen. Some of the portal blood vessels (portal veins and arteries) were moderately dilated. While Photo (2.c), liver sections in group fed on crackers without any additives (G3) represented by mild to modest overcrowding of the portal blood vessels, sinusoidal dilatation , billiard hyperplasia, sometime associated with fibroplasia beside degenerative changes in some hepatocytes mainly cloudy swelling and hydropic degeneration. A few apoptotic cells were seen. Such lesions were observed in some sections. Other liver sections were apparently normal with a healthy hepatic parenchyma, portal areas, vascular and stromal structures. On the experiential also Photo (2.d), liver sections in group fed on crackers $10 \%$ peas peels (G4) exposed normal hepatocytes in the majority piece of the examined tissue though a little hepatocytes were seen suffering cloudy swelling , hydropic degeneration and apoptotic changes. The portal tirades were normal in most areas of investigation with a minor vascular dilatations, and biliary proliferation. The hepatic sinusoids in some areas of the hepatic lobules were mildly dilated and the Von kupffer's cells were prominent. Photo (2.e), examined serial sections from liver of this group fed on crackers 10\% tangerine peels (G5) revealed apparently normal hepatic parenchyma and stroma with usual concord of hepatic lobules, hepatic cords, middle veins, sinusoids and VonKuffer cells. In some sections, mild biliary proliferation was seen. This results agree previous studies with Arkkila et al., (2001), who description that high activities of serum amino transferees have a general symbol of liver and cardiovascular diseases and experimental often between people by diabetes than in the common people. 
Hanan S. Shalaby and Hanan El-Sayed

\section{Kidney sections}

Kidney sections of negative control group (G1) demonstrated renal parenchyma and stroma (3.a), 1 with keeping normal features of the nephron units (glomeruli, proximal and distal convoluting tubules beside loop of Henley). The collecting tubules, papillary and pelvic structures beside stoma and vascular structures were also apparently normal. While in Photo (3.b), positive control group (G2) renal serial sections revealed variable degrees of degenerative effects including, vacuolar and hydropic degeneration mild dilatation of distal convoluted and collecting tubules with partial atrophy of their lining epithelium. A few apoptotic cells were seen in the tubular epithelium. Peculiar perivascular edema and mild to moderate congestion of intertubular and glomerular blood vessels and capillaries sometimes with erythrocytic extravasations were seen. Moderate number of the glomeruli appeared with shrinkage or lobulation of their capillary tufts.
Photo (3.c), examined kidney sections of group fed on crackers without any additives (G3) and revealed mild congestion of renal blood vessels sometimes with mild edematous changes, degenerative and apoptotic changes in some tubular epithelia. Some glomeruli showed shrinkage or lobulation of their capillary tufts .On the other hand Photo(3.d), observed group fed on crackers $10 \%$ peas peels $(\mathrm{G} 4)$, sections from kidney revealed apparently normal histomorphology of nephron unites with a keeping normal features of glomeruli, tubules, papillae, pelvis, vasculature and stroma. Few sections revealed soft congestion of renal blood vessels, per vascular edema and degenerative effects (cloudy swelling and hydropic degeneration) in a little of tubular epithelia. A few glomeruli appeared with shrieked or lobulated capillary tufts and prominent Juxta glomerular apparatus .While Photo (3.e), group fed on crackers $10 \%$ tangerine peels (G5), Kidney sections revealed 
Hanan S. Shalaby and Hanan El-Sayed

normal histo-morphology of nephron components in approximately every the assessor sections with observance skin of normal glomeruli, proximal and distal complicated tubules nearby loops of Henle. Accumulating tubules, renal papillae and renal pelvis. The renal blood vessels and intertubular capillaries were also in a good condition. A few sections denoted mild lobulation of the glomerular capillary tufts and tubular degeneration, mainly hydropic .This results agree with Mojzer et al., (2016) and Amr, (2011), who reported that tangerine polyphenols were of good healthy beneficial effects and have had the abilities to scavenge ROS and reactive nitrogen species and prevent hepatic injury associated with diabetes

\section{CONCLUSION}

Crackers containing of peas and tangerine peels are rich sources of dietary fiber and antioxidant properties. Therefore, it could be recommended to feeding on crackers containing peas and tangerine peels were produced by the lowest cost as defend against diseases it could be reduce blood glucose, beneficial healthy liver and kidney functions, improving antidiabetic

\section{REFERENCES}

Abd- Allah IMA; Rabie

MAD; Mustafa MM;

Suliman AM and El-Badawi

AA (2016):

Nutritional evaluation, chemical composition and antioxidant activity of some food processing wastes. Zagazig Journal of Agricultural Research, 43, 2115 2132.

\section{Ahmed $Z$ and Abozed SS (2014):}

Functional and antioxidant properties of novel snack crackers incorporated with Hibiscus sabdariffa byproduct. J. of Advanced Res., Cairo University. 50, 59-68.

Amr AR (2011): 
Conceivable Effect of feeding Crackers Containing Peas and Tangerine Peels on

Rats with diabetes induced by alloxan

Hanan S. Shalaby and Hanan El-Sayed

Beneficial Health Effe-

cts of Citrus Peels in

Alloxan-Induced Dia-

betic Rats. Egypt. J.

Nutri. and Health, 6, 1-

29.

Ana Angelica HF; Ethel LB; Ary FJ and Cristiano MG (2009):

Effect of Naringerin on

Biochemical parameters in the streptozotocin-induced diabetic rats. Brazilian Archives of Biol. and Technol. 52, 51-59.

AOAC, (2012):

Official Methods of Analysis. Association of Official Analytical Chemistry (A.O.A.C) International, 19th ed., Gaithersburg, Maryland, USA.

\section{Arkkila PET; Koskinen PJ;} Kantola IM and Viikari JS (2001):

Diabetic complications are associated with liver enzyme activities in people with type 1 diabetes. Diabetes Res. and Clinical Practice, 52, 113-118.

Aslan M; Deliorman DO; Orhan N; Sezik E and Yesilada E (2007a):

In vivo antidiabetic and antioxidant potential of Helichrysumplicatum ssp Plicatumcapitulums in streptozotocininduced diabetic rats. $J$. Ethnophar, 109, 54-59.

Aslan M; Deliorman D; Orhan N; Sezik E and Yesilada E (2007b):

A study of antidiabetic and antioxidant effects of Helichrysum ssp. Graveolenscapitulums in streptozotocininduced diabetic rats. $J$. Med. Foods, 10, 396400.

Balasubramaian R; Kasiappan R; Vengidusamy N; Muthusamy $K$ and Sorimuthu S (2004):

Protective effect of macrocyclic binuclear oxovanadium complex on oxidative stress in pancreas of streptozotocin induced 
Conceivable Effect of feeding Crackers Containing Peas and Tangerine Peels on

Rats with diabetes induced by alloxan

Hanan S. Shalaby and Hanan El-Sayed

diabetic rats. Chemico-

Biol. Inter., 149, 9-21.

Belghith L; Fendri F; Chaari M; Maaloul F; Kallel L; Abdelkafi S; Ellouz $\mathrm{C}$ and Dhouha G (2016):

Wheat bread enrichment by pea and broad bean pods fibers: Effect on dough rheology and bread quality. LWT Food Sci. and Tech., 73, 584-591.

Boynes JW (1991):

Role of oxidative stress in the development of complication in diabetes. Diabetes 40, 405-411.

\section{CDCP (Centers for Disease} Control and Prevention) (2020):

What is Diabetes?" and The top 10 causes of death.

Chiba H; Uehara M; Wu J; Wang X; Masuyama R; Suzuki K; Kanazawa $\mathrm{K}$ and Ishimi Y (2003):

Hesperidin, a Citrus flavonoid, inhibits bone loss and decreases serum and hepatic lipids in ovariectomized mice. J. Nutr, 133, 1892- 1897.

Devi $R$ and Sharma DK (2004):

Hypolipidemic effect of different extracts of Clerodendroncolebroo kianumWalp in normal and high-fat diet fed rats. J. Ethnopharmacol., 90, 63-68.

Dokić L; Pajin B; Fišteš A; Šereš Z; Simović DŠ and Krstonošić V (2015):

Rheological and textural properties of cracker dough with the addition of pea dietary fiber. Acta Periodic. Technol., 46, 29-35.

Eliza J; Daisy P; Ignacimuthu $S$ and Duraipandiyan V (2009):

Normo-glycemic and hypolipidemic effect of costunolide isolated from Costusspeciosus (Koen ex. Retz.)Sm. in streptozotocin-induced 
Conceivable Effect of feeding Crackers Containing Peas and Tangerine Peels on

Rats with diabetes induced by alloxan

Hanan S. Shalaby and Hanan El-Sayed

diabetic rats. Chem.

Biol. Interact, 179,

329-334.

Elleuch M; Bedigian D;

Roiseux O; Besbes S; Blecker

$C$ and Attia $H$ (2011):

Dietary fibre and fibre

rich by-products of

food processing: Characterization, technological functionality and commercial application; a review. . Food Chem. J., 124, 411421.

Fernandez-Gines

JM;

Fernandez-Lopez J; Sayas-

Barbera E; Sendra E and

Perez Alvarez JA (2003):

Effect of storage conditions on quality characteristics of bologna sausages made with citrus fiber. $J$. Food Sci., 68, 710-715.

Figuerola F; Hurtado ML; Estevez AM; Chiffelle I and Asenjo F (2005):

Fiber concentrates

from apple pomace and citrus peel as potential fiber sources for food
Garg, M. (2015).

Nutritional evaluation and utilization of pea pod powder for preparation of jaggery biscuits. Journal of Food Processing and Technology, 6(12), 1013

Gulcin I; Kufrevioglu OI; Oktay M and Buyukokuroglu ME (2004):

Antioxidant, antimicrobial, antiulcer and analgesic activities of nettle (Urticadioica L.) Journal of Ethnopharmacology.90, 205215.

Hamden K; Carreau S; Lajmi S; Aloulou D; kchaou $D$ and Elfeki A (2008):

Hyperglycemia, stress oxidant, liver dysfunction and histological changes induced by alloxan in male rat pancreas and liver: Protective effect of 17"- 
Conceivable Effect of feeding Crackers Containing Peas and Tangerine Peels on

Rats with diabetes induced by alloxan

Hanan S. Shalaby and Hanan El-Sayed

estradiol on, Steroids

94, 495-501.

Han J; Janz JAM and Gerlat M (2010):

Development of glutenfree cracker snacks using pulse flours and fractions. Food Res. International , 43, 627633.

Hanato T; Kagawa $\mathbf{H}$; Yasuhara $T$ and Okuda $T$ (1988):

Two new flavonoids and other constituents in licorice root: their relative astringency and radical scavenging effects. J. of Chem. Pharm. Bul. 36, 20902097.

\section{Herath HMT; Dinesha-} Tharangani -Rupasinghe KM; Priyangani1 D and De Silva MSW (2018):

Formulation and Physicochemical properties of dietary fiber enhanced low glycemic multi-grain Cracker for adults using locally available cereals and legumes. Res. J. of

Chemical science. 8, 1-

8.

\author{
Hogan P; Dall, T and Nikolov \\ $P$ (2003): \\ Economic costs of \\ diabetes in the U.S. in \\ 2002. Diabetes Care, \\ 26, 917-32.
}

Huang TH; Kota BP; Razmovski V and Roufogalis BD (2005):

Herbal or natural medicines as modulators of peroxisome proliferator-activated receptors and related nuclear receptors for therapy of metabolic syndrome. Basic Clin. Pharmacol. Toxicol. 96, 3-14.

Jarald EE; Joshi SB and Jain, DC (2008):

Antidiabetic activity of aqueous extract and non-polysaccharide fraction of Cynodondactylon Pers. Indian J. of Experimental Biol., 46, 660-667. 
Conceivable Effect of feeding Crackers Containing Peas and Tangerine Peels on

Rats with diabetes induced by alloxan

Hanan S. Shalaby and Hanan El-Sayed

Jelodar G; Khaksar $Z$ and Pourahmadi M (2010):

Endocrine profile and testicular histomorphometry in neonatal rats of diabetic mothers. Vet Arhiv, 80, 421-430.

Johnson R; McNutt P; MacMahon $S$ and Robson $R$ (1997):

Use of the friedewald formula to estimate LDL-cholesterol in patients with chronic renal failure on dialysis. J. of Clin. Chem., 4, 2183-2184.

Julius O; Ebangha E; Shil K; Walter C; Robert $G$ and Deanne D (2008):

Phellodendron and Citrus extracts benefit cardiovascular health in osteoarthritis patients: a doubleblind, placebocontrolled pilot study. Nutr. J., 7, 16.

Kamal DMM; Azad MdA; Kabir MdS and Azad AB (2016
Processing and Quality

Evaluation of Crackers from Cassava Flour Int. Res.J. Biol.Sci. 5, 2225.

Kirtikar KK and Basu BD (1988):

Indian medicinal plants, (Lalit Mohan Publication, India), $\mathrm{P}$ 2650.

Lafrance L; Rabasa R; Poisson D; Ducros F and Chiassion JL (1998):

Effects of different glycemic index food and dietary fiber intake on glycemic control in Type I diabetic patients on intensive insulin therapy. Diabet. Med., 15, 972-978.

Lenzen $S$ and Panten $U$ (1988):

Alloxan: history and mechanism of action. Diabetologia, 31, 337342.

Li ZQ; Zhao ZY and Zhou ZQ (2018): 
Conceivable Effect of feeding Crackers Containing Peas and Tangerine Peels on

Rats with diabetes induced by alloxan

Hanan S. Shalaby and Hanan El-Sayed

Simultaneous Sepa-
ration and Purification
of Five Polymethoxy-
lated Flavones from
"Dahongpao" Tange-
rine (Citrus tangerina
Tanaka) Using Macro-
porous Adsorptive
Resins Combined with
Prep-HPLC.Molecules,
23, 2660.

Y; Zeng W; Huang KE; Li DX; Chen W; Yu XQ and Ke XH (2019):

Preparation of Jaggery

biscuits. J. Food

Process Technol., 6,

522.

Mejri F; Khoud HB; Njim L;

Baati T; Selmi S; Martins A and Hosni K (2019):

In vitro and in vivo

biological properties of

pea pods (Pisum

sativum L.). Food

Bioscience, 32,

100482. ivum L.). Food

Bioscience, 32, 100482.

Discrimination of

Citrus reticulate Blanco

and Citrus reticulata

'Chachi' as well as the

Citrus reticulata

'Chachi' within die rent

storage years using

ultra high performance

liquid chromatography

quadrupole/time-of-

flight mass spectro-

metry based meta-

bolemics approach. $J$.

Pharm. Biomedical

Anal. 171, 218-231.

Meenakshi G (2015):

Nutritional Evaluation

and Utilization of Pea

Pod Powder for

Miyake Y; Yamamoto K; Tsujihara $\mathbf{N}$ and Osawa $T$ (1998):

Protective effects of lemon flavonoids on oxidative stress in diabetic rats. Lipids, 33, 689-695.

Mohamed SS and Fayed AM (2020):

Anti-Obesity Synergistic Effect of Pomegranate Seed Oil (PSO) and Arabic Gum (AG) in Albino Rats. Int. J.. Vet. Sci., 9, 8489. 
Conceivable Effect of feeding Crackers Containing Peas and Tangerine Peels on

Rats with diabetes induced by alloxan

Hanan S. Shalaby and Hanan El-Sayed

Mojzer EB; Hrncic MK;

Škerget $M$; Knez $\breve{Z}$ and Bren

U (2016):

Polyphenols: Extraction Methods, Antioxidative Action, Bioavailability and Anticarcinogenic Effects .Molecules, 21, 2-38.

Moure MQ; Anderson RF and Jonah KR (2001):

Chapter 2 - food science basics: healthy cooking and baking demystified the science behind healthy foods, cooking and baking. Culinary Nutri.. 51-97.

\section{O'Shea N; Kilcawley KN and} Gallagher E (2017):

Aromatic Composition and Physicochemical Characteristics of Crackers Containing Barley Fractions. Cereal Chem., 94, 611-618.

Reeves PG; Nielsen FH and Fahey GCJ (1993):

AIN-93 purified diets for laboratory rodents: final report of the American Institute of
Nutrition ad hoc writing committee on the reformulation of the AIN 76A rodent diet. $J$. Nutr., 123:1939-1951.

Rodríguez R; Jimenez A; Fernández-Bolanos $\quad \mathbf{J}$; Guillen $R$ and Heredia A (2006):

Dietary fiber from vegetable products as source of functional ingredients. Trends in Food Sci., \& Technol., 17, 3-15.

Roudaut G; Dacremont C and Meste ML (1998):

Influence of water on the crispness of cerealbased foods: acoustic, mechanical, and sensory studies. Journal of Texture Studies. 29, 199-213. https://doi.org/ 10.1111 /j.17454603.1998.tb00164.x.

Shafiya R; Rajkumari K; Sofi SA; Bashir N; Nazir F; Ahmad $G$ and Nayik c (2018):

Citrus peel as a source of functional ingre- 
Conceivable Effect of feeding Crackers Containing Peas and Tangerine Peels on

Rats with diabetes induced by alloxan

Hanan S. Shalaby and Hanan El-Sayed

dient: A Review. J. of

the Saudi Society of

Agric. Sci., 17, 351-

358.

Shiban MS; Al Otaibi MM and Al-Zoreky NS (2012):

Antioxidant activity of pomegranate

(Punicagranatum

fruit peels. Food Nutr.

Sci. 3, 991-996.

Shoback DG and Gardner D, (2011):

"Chapter

17". Greenspan's basic

and clinical endocri-

nology (9th ed.). New

York: McGraw-Hill

Medical International

DIABETES Federation

(IDF) 2019:

DIABETES ATLAS

Ninth edition

Skerget M; Kotnik P; Hadolin M; Riz;ner-Hras SA and Knez M (2005):

Phenols, proanthocyanidins, flavones and flavonols in some plant materials and their antioxidant activities. $J$. of Food Chem., 89,

191-198.

Sry SW; Rusdiana D and Maya S (2019):

Glucose Lowering

Effect of Basil Leaves in Diabetic Rats. Open Access Maced J Med Sci. 7, 1415-1417.

Steel RG; D and Torrie JH (1980):

Principles and Procedures of Statistics. A biometrical approach. 2nd edition. McGrawHill, New York, USA, pp. 20-90.

Sudha ML; Vetrimani R and Leelawathi K (2007):

Influence of Fiber from Different Cereals on the Rheological Characteristics of Wheat Flour Dough and on Biscuit Quality. J. Food Chem., 100, 13651370.

Suvarna Kim S; Christopher L and Bancroft JD (2013): 
Conceivable Effect of feeding Crackers Containing Peas and Tangerine Peels on

Rats with diabetes induced by alloxan

Hanan S. Shalaby and Hanan El-Sayed

Bancroft's Theory and

Practice of Histological

Techniques, $7^{\text {th }} \mathrm{Ed}$ ).

Terpstra AH; Lapre JA;

Vries HT and Beynen AC (2002):

The hypocholestero-

lemia effect of lemon

peels, lemon pectin,

and the waste stream

material of lemon peels

in hybrid F1B hamsters.

Eur. J. Nutr., 41, 19-

26.

Verma SK and Bordia A (1998):

Antioxidant property of Saffron in man. Indian J. Med. Res., 52, 205207.

Vos T; Flaxman AD; Naghavi M; Lozano R; Michaud Cand Ezzati M (2012):

"Years lived with disability (YLDs) for 1160 sequelae of 289 diseases and injuries 1990-2010: a systematic analysis for the Global Burden of Disease Study 2010"
Waheby R (2018):

Using Dietary Fibers in Fortification Some Foods and Dairy Products Food Science Department, Faculty of Agriculture, Zagazig University. 2018 Doctor of Philosophy.

Wang F; Chen L; Chen H; Chen S and Liu Y (2019):

Analysis of Flavonoid Metabolites in Citrus Peels (Citrus reticulata "Dahongpao") Using UPLC-ESI-MS/MS.

Molecules, 24, 2680.

\section{Wang L; Wang J; Fang L; Zheng Z; Dexian Z; Wang S; Li S; Ho CT and Zhao $H$ (2014):}

Anticancer activities of citrus peel polymethoxyflavones related to angiogenesis and others. Biomed. Res. Inr.

Wanyo P; Chomnawang C and Siriamornpun $S$ (2009):

Substitution of wheat flour with rice flour and rice bran in flake 
Conceivable Effect of feeding Crackers Containing Peas and Tangerine Peels on Rats with diabetes induced by alloxan

Hanan S. Shalaby and Hanan El-Sayed products: effects on Zhang SJ; Hu TT; Chen YY; chemical, physical and antioxidant properties. Wang $S$ and Kang YF (2020): World Applied Sci. J., 7, 49-56.

World Health Organization (2008):

Diagnosis and classification of diabetes mellitus and its Analysis of the polysaccharide fractions isolated from pea (Pisum sativum L.) at different levels of purification. Journal of Food Biochemistry, 44, e13248.

compilation. Department of Noncommunicable Disease Surveillance, Geneva.

\section{Young DS (2001):}

Effects of disease on clinical lab tests, $4^{\text {th }}$ ed. AACC. Clin. Chem., 48, Pp. 682.

Zydenbos S and HumphreyTaylor V (2003):

Biscuit, cookies and crackers Nature of the products (book).in Encyclopedia of Food Sciences and Nutrition (Second Edition). 
Conceivable Effect of feeding Crackers Containing Peas and Tangerine Peels on

Rats with diabetes induced by alloxan

Hanan S. Shalaby and Hanan El-Sayed

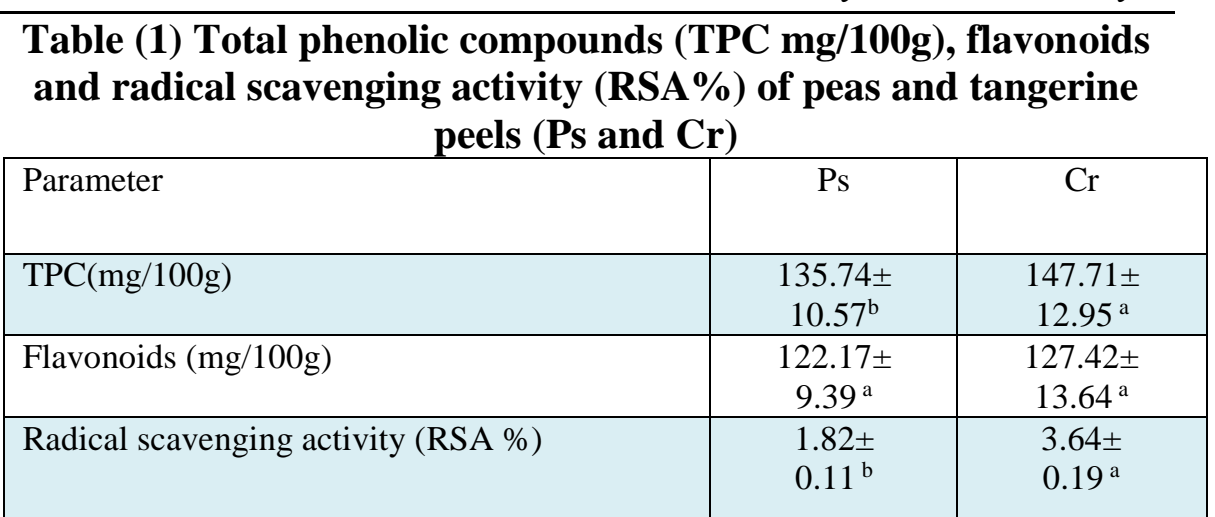

Each value represents the mean of three replicates $\pm S D$. Means with the different superscript letters are significantly different at $p \leq 0.05$. Ps: Peas peels powder extract $\boldsymbol{C r}$ : Tangerine peels powder extract

\section{Table (2) Chemical composition of crackers and peas and tangerine peels powder}

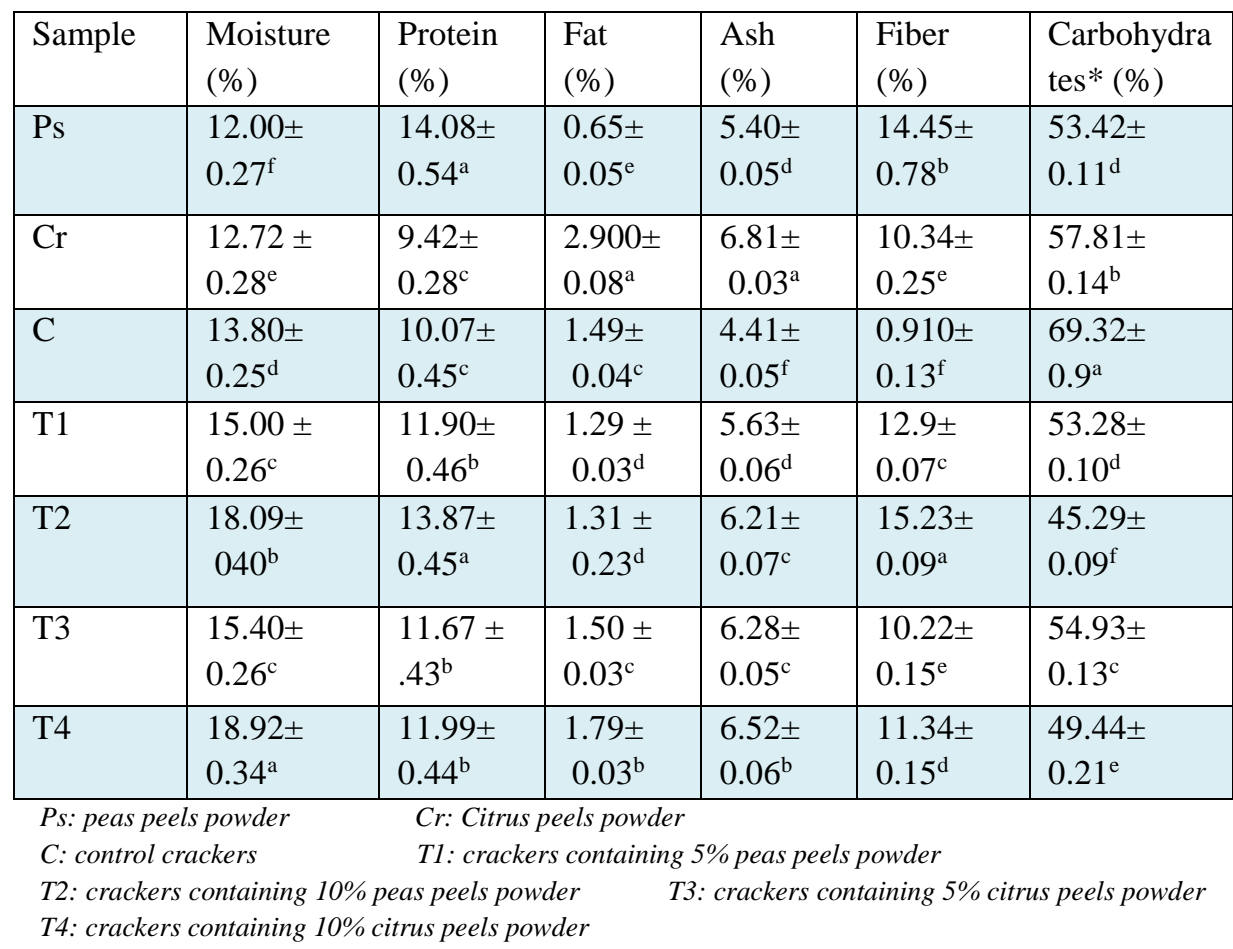


Conceivable Effect of feeding Crackers Containing Peas and Tangerine Peels on

Rats with diabetes induced by alloxan

Hanan S. Shalaby and Hanan El-Sayed

Table (3): Organoleptic properties of crackers products

\begin{tabular}{|c|c|c|c|c|c|c|}
\hline Sample & $\begin{array}{l}\text { Odor } \\
\text { (9) }\end{array}$ & $\begin{array}{l}\text { Color } \\
(9)\end{array}$ & $\begin{array}{l}\text { Appearan } \\
\text { ce } \\
(9)\end{array}$ & $\begin{array}{l}\text { Taste } \\
\text { (9) }\end{array}$ & $\begin{array}{l}\text { Crispness } \\
\text { (9) }\end{array}$ & $\begin{array}{l}\text { Overall } \\
\text { Acceptabili } \\
\text { ty (9) }\end{array}$ \\
\hline $\mathrm{C}$ & $\begin{array}{l}8.75 \pm \\
0.462^{\text {ab }}\end{array}$ & $\begin{array}{l}8.87 \pm \\
0.991^{\text {ab }}\end{array}$ & $\begin{array}{l}9.12 \pm \\
0.640^{\mathrm{a}}\end{array}$ & $\begin{array}{l}8.75 \pm \\
0.886^{\text {ab }}\end{array}$ & $\begin{array}{l}8.37 \pm \\
0.916^{b}\end{array}$ & $\begin{array}{l}9.00 \pm \\
0.000^{\mathrm{ab}}\end{array}$ \\
\hline $\mathrm{T} 1$ & $\begin{array}{l}8.00 \pm \\
1.309^{\mathrm{b}}\end{array}$ & $\begin{array}{l}7.87 \pm \\
1.457^{\mathrm{b}}\end{array}$ & $\begin{array}{l}8.25 \pm \\
1.388^{\mathrm{ab}}\end{array}$ & $\begin{array}{l}8.12 \pm \\
1.726^{\mathrm{b}}\end{array}$ & $\begin{array}{l}8.62 \pm \\
1.060^{\mathrm{ab}}\end{array}$ & $\begin{array}{l}6.75 \pm \\
8.253^{c}\end{array}$ \\
\hline $\mathrm{T} 2$ & $\begin{array}{l}8.00 \pm \\
1.603^{b}\end{array}$ & $\begin{array}{l}7.84 \pm \\
1.457^{\mathrm{b}}\end{array}$ & $\begin{array}{l}7.75 \pm \\
1.035^{\mathrm{b}}\end{array}$ & $\begin{array}{l}8.00 \pm \\
1.772^{\mathrm{b}}\end{array}$ & $\begin{array}{l}8.50 \pm \\
0.925^{\mathrm{b}}\end{array}$ & $\begin{array}{l}7.25 \pm \\
8.843^{b}\end{array}$ \\
\hline T3 & $\begin{array}{l}8.87 \pm \\
0.640^{\mathrm{ab}}\end{array}$ & $\begin{array}{l}9.62 \pm \\
0.517^{\mathrm{a}}\end{array}$ & $\begin{array}{l}9.25 \pm \\
0.886^{a}\end{array}$ & $\begin{array}{l}8.87 \pm \\
1.069^{\mathrm{ab}}\end{array}$ & $\begin{array}{l}8.75 \pm \\
1.164^{\mathrm{a}}\end{array}$ & $\begin{array}{l}6.87 \pm \\
7.646^{c}\end{array}$ \\
\hline $\mathrm{T} 4$ & $\begin{array}{l}9.00 \pm \\
0.755^{\mathrm{a}}\end{array}$ & $\begin{array}{l}9.12 \pm \\
0.834^{\mathrm{a}}\end{array}$ & $\begin{array}{l}9.00 \pm \\
0.755^{\mathrm{a}}\end{array}$ & $\begin{array}{l}9.00 \pm \\
0.834^{\mathrm{a}}\end{array}$ & $\begin{array}{l}8.82 \pm \\
1.060^{\mathrm{ab}}\end{array}$ & $\begin{array}{l}9.50 \pm \\
7.071^{\mathrm{a}}\end{array}$ \\
\hline LSD & 1.850 & 1.393 & 1.303 & 0.408 & 2.225 & 3.025 \\
\hline
\end{tabular}

Table (4) Effect of feeding crackers on levels of rats' blood glucose

\begin{tabular}{|c|c|c|}
\hline Feeding period(weeks) & Groups & $\begin{array}{l}\text { Blood glucose } \\
(\mathrm{mg} / \mathrm{dl})\end{array}$ \\
\hline \multirow[t]{2}{*}{ The initial } & $-\mathrm{Ve}$ & $\begin{array}{l}121.667 \pm \\
10.40^{\mathrm{e}}\end{array}$ \\
\hline & $+\mathrm{Ve}$ & $\begin{array}{l}296.583 \pm \\
10.98^{\mathrm{b}}\end{array}$ \\
\hline \multirow[t]{6}{*}{ The end } & G1 & $\begin{array}{l}111.790 \pm \\
13.37^{\mathrm{e}}\end{array}$ \\
\hline & G2 & $\begin{array}{l}370.410 \pm \\
24.19^{\mathrm{a}}\end{array}$ \\
\hline & G3 & $\begin{array}{l}285.537 \pm \\
7.61^{\mathrm{b}}\end{array}$ \\
\hline & G4 & $\begin{array}{l}215.250 \pm \\
11.09^{\mathrm{c}} \\
\end{array}$ \\
\hline & G5 & $\begin{array}{l}155.973 \pm \\
8.49^{\mathrm{d}}\end{array}$ \\
\hline & LSD & 3.3663 \\
\hline
\end{tabular}

Values with different superscript letters in the same column are significantly different at $P \leq$ 0.05. -Ve: Negative control group +Ve: Positive control group

G1 : Rats (negative control group) fed on feeding normal all research period.

G2: Positive control diabetic rats. G3: Diabetic group fed on crackers without any additives G4: Diabetic group fed on crackers containing $10 \%$ peas peels. 
Conceivable Effect of feeding Crackers Containing Peas and Tangerine Peels on

Rats with diabetes induced by alloxan

Hanan S. Shalaby and Hanan El-Sayed

G5: Diabetic group fed on crackers containing $10 \%$ tangerine peels.

Table (5) Impact of feeding crackers on serum lipid profile of diabetic rats.

\begin{tabular}{|l|l|l|l|l|l|l|}
\hline $\begin{array}{l}\text { Feeding } \\
\text { period } \\
\text { (weeks) }\end{array}$ & Group & $\begin{array}{l}\text { T.C } \\
(\mathrm{mg} / \mathrm{dl})\end{array}$ & $\begin{array}{l}\text { T.G } \\
(\mathrm{mg} / \mathrm{dl})\end{array}$ & $\begin{array}{l}\text { HDL } \\
(\mathrm{mg} / \mathrm{dl})\end{array}$ & $\begin{array}{l}\text { LDL } \\
(\mathrm{mg} / \mathrm{dl})\end{array}$ & $\begin{array}{l}\text { VLDL } \\
(\mathrm{mg} / \mathrm{dl})\end{array}$ \\
\hline $\begin{array}{l}\text { The } \\
\text { initial }\end{array}$ & $\mathbf{- V e}$ & $\begin{array}{l}119.170 \pm \\
8.66^{\mathrm{e}}\end{array}$ & $\begin{array}{l}85.240 \pm \\
0.87^{\mathrm{e}}\end{array}$ & $\begin{array}{l}56.133 \pm \\
1.32^{\mathrm{ab}}\end{array}$ & $\begin{array}{l}45.990 \pm \\
7.75^{\mathrm{e}}\end{array}$ & $\begin{array}{l}17.047 \pm \\
0.17^{\mathrm{e}}\end{array}$ \\
\cline { 2 - 7 } & $\mathbf{+ V e}$ & $\begin{array}{l}126.750 \pm \\
9.16^{\mathrm{e}}\end{array}$ & $\begin{array}{l}146.867 \pm \\
9.75^{\mathrm{a}}\end{array}$ & $\begin{array}{l}66.667 \pm \\
18.50^{\mathrm{a}}\end{array}$ & $\begin{array}{l}30.710 \pm \\
9.80^{\mathrm{f}}\end{array}$ & $\begin{array}{l}29.373 \pm \\
1.94^{\mathrm{a}}\end{array}$ \\
\hline \multirow{3}{*}{ The end } & $\mathbf{G 1}$ & $120.75 \pm$ & $88.053 \pm$ & $54.920 \pm$ & $48.227 \pm$ & $17.610 \pm$ \\
& & $13.66^{\mathrm{e}}$ & $2.49^{\mathrm{e}}$ & $0.45^{\mathrm{ab}}$ & $13.48^{\mathrm{e}}$ & $0.49^{\mathrm{e}}$ \\
\cline { 2 - 7 } & $\mathbf{G 2}$ & $263.615 \pm$ & $153.070 \pm$ & $44.803 \pm$ & $188.200 \pm$ & $30.610 \pm$ \\
& & $6.56^{\mathrm{a}}$ & $8.25^{\mathrm{a}}$ & $0.69^{\mathrm{c}}$ & $4.21^{\mathrm{a}}$ & $1.65^{\mathrm{a}}$ \\
\cline { 2 - 7 } & $\mathbf{G 3}$ & $197.160 \pm$ & $126.330 \pm$ & $48.900 \pm$ & $123.097 \pm$ & $25.263 \pm$ \\
& $2.91^{\mathrm{b}}$ & $5.78^{\mathrm{b}}$ & $0.95^{\mathrm{c}}$ & $2.71^{\mathrm{b}}$ & $1.16^{\mathrm{b}}$ \\
\cline { 2 - 7 } & $\mathbf{G 4}$ & $181.200 \pm$ & $112.680 \pm$ & $51.400 \pm$ & $107.263 \pm$ & $22.530 \pm$ \\
& & $2.96^{\mathrm{c}}$ & $2.86^{\mathrm{c}}$ & $0.85^{\mathrm{c}}$ & $4.38^{\mathrm{c}}$ & $0.57^{\mathrm{c}}$ \\
\cline { 2 - 7 } & $\mathbf{G 5}$ & $156.165 \pm$ & $99.115 \pm$ & $53.200 \pm$ & $83.145 \pm$ & $19.820 \pm$ \\
& & $5.45^{\mathrm{d}}$ & $3.29^{\mathrm{d}}$ & $0.46^{\mathrm{c}}$ & $5.25^{\mathrm{d}}$ & $0.66^{\mathrm{d}}$ \\
\hline
\end{tabular}

Values with different superscript letters in the same column are significantly different at $P \leq$

0.05. -Ve: Negative control group +Ve: Positive control group G1: Rats (negative control group) fed on feeding normal all research period. G2: Positive control diabetic rats. G3: Diabetic group fed on crackers without any additives G4: Diabetic group fed on crackers containing 10\% peas peels. G5: Diabetic group fed on crackers containing 10\% tangerine peels.

Table (6) Impact of feeding crackers on liver functions

\begin{tabular}{|l|l|l|l|l|}
\hline $\begin{array}{l}\text { Feeding } \\
\text { period }\end{array}$ & Group & $\begin{array}{l}\text { ALT } \\
(\mathrm{U} / \mathrm{L})\end{array}$ & $\begin{array}{l}\text { AST } \\
(\mathrm{U} / \mathrm{L})\end{array}$ & $\begin{array}{l}\text { T.P } \\
(\mathrm{g} / \mathrm{dl})\end{array}$ \\
\hline \multirow{3}{*}{$\begin{array}{l}\text { The } \\
\text { initial }\end{array}$} & $\mathbf{- V e}$ & $69.403 \pm$ & $145.193 \pm$ & $6.403 \pm$ \\
& & $4.63^{\mathrm{d}}$ & $28.28^{\mathrm{c}}$ & $0.22^{\mathrm{a}}$ \\
\cline { 2 - 5 } & $\mathbf{+ V e}$ & $38.320 \pm$ & $96.467 \pm$ & $7.157 \pm$ \\
& $15.05^{\mathrm{e}}$ & $2.46^{\mathrm{d}}$ & $0.17^{\mathrm{a}}$ \\
\hline \multirow{2}{*}{ The end } & $\mathbf{G 1}$ & $27.093 \pm$ & $111.643 \pm$ & $6.960 \pm$ \\
& & $4.97^{\mathrm{e}}$ & $13.57^{\mathrm{d}}$ & $0.11^{\mathrm{b}}$ \\
\cline { 2 - 5 } & $\mathbf{G 2}$ & $130.733 \pm$ & $217.803 \pm$ & $5.180 \pm$ \\
& & $133.43^{\mathrm{a}}$ & $7.30^{\mathrm{a}}$ & $0.07^{\mathrm{d}}$ \\
\cline { 2 - 5 } & $\mathbf{G 3}$ & $102.953 \pm$ & $176.930 \pm$ & $5.570 \pm$ \\
& & $1.29^{\mathrm{b}}$ & $3.51^{\mathrm{bc}}$ & $0.50^{\mathrm{c}}$ \\
\cline { 2 - 5 } & $\mathbf{G 4}$ & $95.780 \pm$ & $158.453 \pm$ & $6.237 \pm$ \\
& & $0.96^{\mathrm{bc}}$ & $2.13^{\mathrm{bc}}$ & $0.30^{\mathrm{b}}$ \\
\cline { 2 - 5 } & $\mathbf{G 5}$ & $87.360 \pm$ & $136.537 \pm$ & $6.197 \pm$ \\
& & $1.81^{\mathrm{c}}$ & $3.88^{\mathrm{c}}$ & $0.23^{\mathrm{b}}$ \\
\hline LSD & 1.1861 & 1.7109 & 0.03276 \\
\hline
\end{tabular}


Hanan S. Shalaby and Hanan El-Sayed

\begin{abstract}
Values with different superscript letters in the same column are significantly different at $P \leq 0.05$. Ve: Negative control group +Ve: Positive control group G1: Rats (negative control group) fed on feeding normal all research period. G2: Positive control diabetic rats. G3: Diabetic group fed on crackers without any additives $\quad$ G4: Diabetic group fed on crackers containing $10 \%$ peas peels. G5: Diabetic group fed on crackers containing $10 \%$ tangerine peels.
\end{abstract}

\title{
Table (7) Impact of feeding crackers on kidney functions
}

\begin{tabular}{|l|l|l|l|}
\hline $\begin{array}{l}\text { Feeding } \\
\text { period }\end{array}$ & Group & $\begin{array}{l}\text { Creatinine } \\
(\mathrm{mg} / \mathrm{dl})\end{array}$ & Urea $(\mathrm{mg} / \mathrm{dl})$ \\
\hline $\begin{array}{l}\text { The } \\
\text { initial }\end{array}$ & -Ve & $0.583 \pm$ & $21.107 \pm$ \\
& & $0.08^{\mathrm{b}}$ & $3.58^{\mathrm{d}}$ \\
\cline { 2 - 4 } & +Ve & $0.567 \pm$ & $27.443 \pm$ \\
& $0.03^{\mathrm{b}}$ & $3.20^{\mathrm{d}}$ \\
\hline The end & $\mathbf{G 1}$ & $0.597 \pm$ & $25.840 \pm$ \\
& & $0.03^{\mathrm{b}}$ & $4.68^{\mathrm{d}}$ \\
\cline { 2 - 4 } & $\mathbf{G 2}$ & $0.963 \pm$ & $79.913 \pm$ \\
& & $0.02^{\mathrm{a}}$ & $8.14^{\mathrm{a}}$ \\
\cline { 2 - 4 } & $\mathbf{G 3}$ & $0.900 \pm$ & $66.630 \pm$ \\
& & $0.02^{\mathrm{a}}$ & $2.38^{\mathrm{b}}$ \\
\cline { 2 - 4 } & $\mathbf{G 4}$ & $0.710 \pm$ & $62.813 \pm$ \\
& & $0.21^{\mathrm{b}}$ & $2.31^{\mathrm{b}}$ \\
\cline { 2 - 4 } & $\mathbf{G 5}$ & $0.700 \pm$ & $53.623 \pm$ \\
& & $0.02^{\mathrm{b}}$ & $1.69^{\mathrm{c}}$ \\
\hline LSD & 0.1566 & 7.4102 \\
\hline
\end{tabular}

Values with different superscript letters in the same column are significantly different at $\mathrm{P} \leq$ 0.05. -Ve: Negative control group +Ve: Positive control group

G1 : Rats (negative control group) fed on feeding normal all research period.

G2: Positive control diabetic rats. G3: Diabetic group fed on crackers without any additives

G4: Diabetic group fed on crackers containing $10 \%$ peas peels.

G5: Diabetic group fed on crackers containing $10 \%$ tangerine peels. 


\section{Conceivable Effect of feeding Crackers Containing Peas and Tangerine Peels on Rats with diabetes induced by alloxan}

Hanan S. Shalaby and Hanan El-Sayed

\section{Pancreas sections}

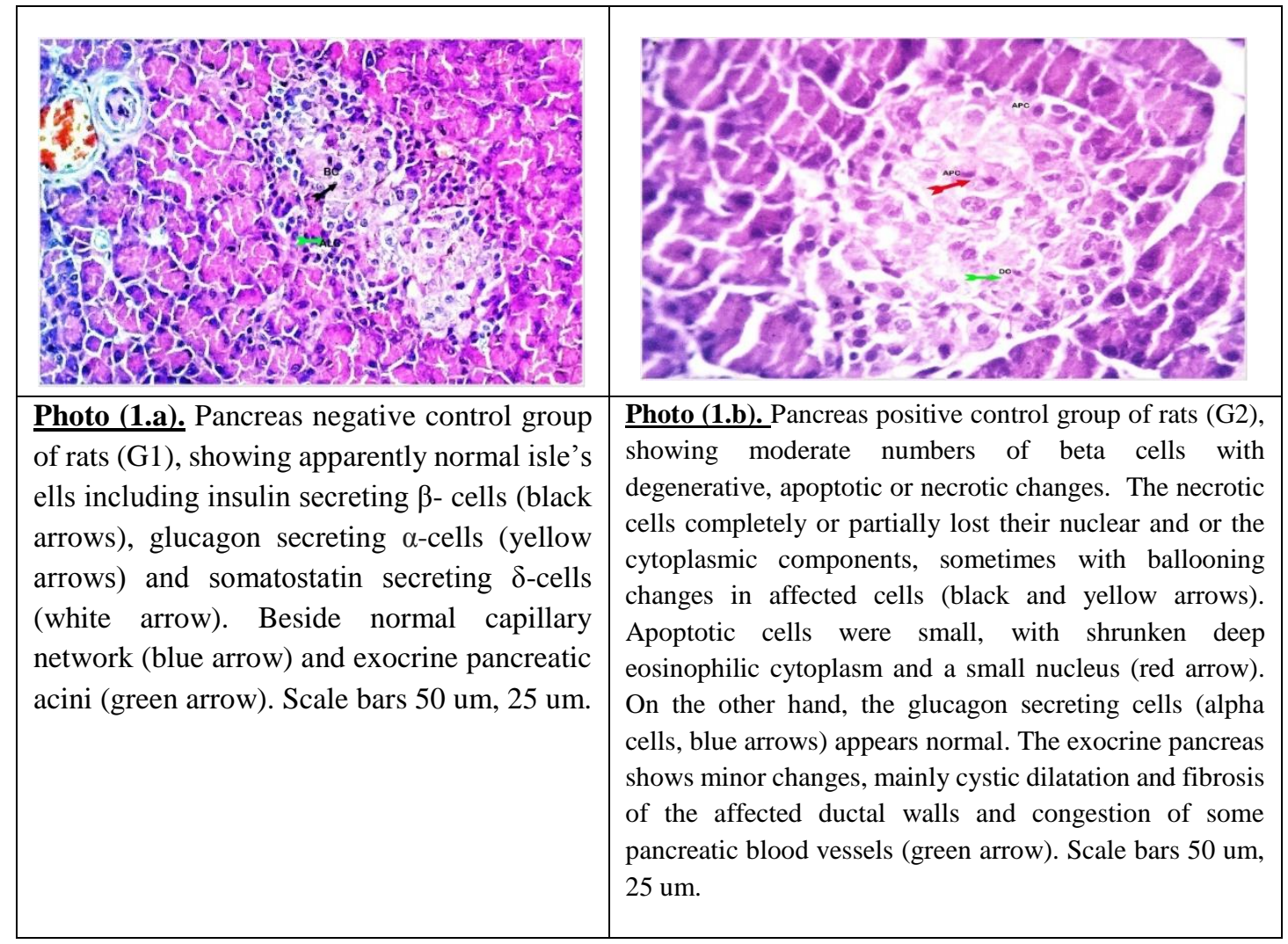




\section{Conceivable Effect of feeding Crackers Containing Peas and Tangerine Peels on Rats with diabetes induced by alloxan}

Hanan S. Shalaby and Hanan El-Sayed

\section{Pancreas sections}

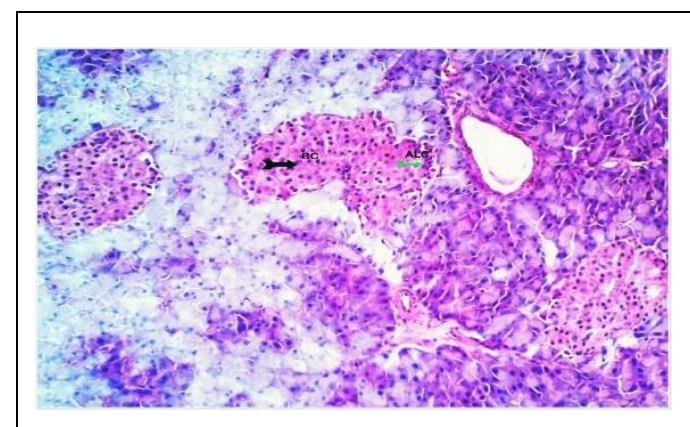

Photo (1.c). Pancreas group fed on crackers without any additives (G3) of rats showing pancreatic islets that regained their normal sizes. Distribution and cellular morphology ( blue and yellow arrows), some of the islets cells particularly beta $(\beta$ - cells) and a few alpha cells ( $\alpha$-cells ) showed mild to modest degenerative changes, mostly overcast swelling and hydropic degeneration,( red arrow ) a few $\beta$ - cellsrevealed early apoptotic and or necrotic changes(gray arrow). Some exocrine ducts were cystically dilated. (Black arrow). Scale bars 50, 25 um

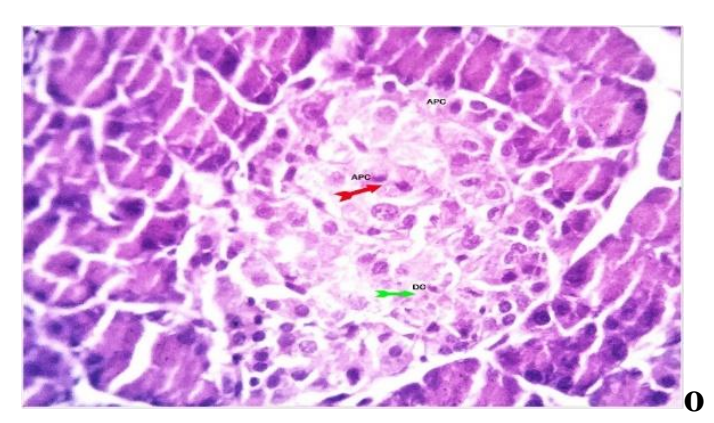

Photo (1.d). Pancreas group fed on crackers 10\% peas peels (G4) of rats showing large islets of Langerhans with activated beta cells and alpha cells (green and blue arrows). A few beta cells shows degenerative changes mostly overcast swelling and hydropic degeneration (red arrow) and early necrotic changes (black arrow) .The exocrine pancreas was almostly normal. Scale bars $50 \mathrm{um}, 25 \mathrm{um}$.

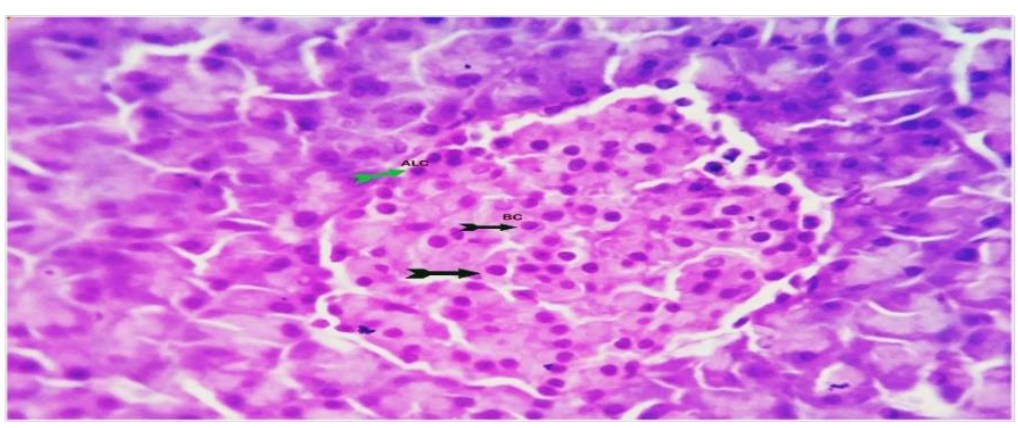

Photo (1.e). Pancreas group fed on crackers $10 \%$ tangerine peels (G5) of rats showing apparently normal endocrine islets. The Beta and alpha cells are healthy and apparently functioning in most parts of the islets (yellow and green arrows). Very view number of beta cells shows hydropic degeneration (black arrow). Scale bars 5o um, 25 um. 


\section{Conceivable Effect of feeding Crackers Containing Peas and Tangerine Peels on Rats with diabetes induced by alloxan}

Hanan S. Shalaby and Hanan El-Sayed

\section{Liver sections}

\begin{tabular}{l} 
Photo Photo (2.a). Liver negative control group of \\
rats (G1), showing preserved hepatic cords( blue \\
arrows), , vascular tributaries( yellow arrows), and \\
$\begin{array}{l}\text { Von kupffer's cells ( red arrow). Scale bars 50um, } 25 \\
\text { um. }\end{array}$ \\
$\begin{array}{l}\text { Photo (2.b). Liver positive control group of rats (G2) } \\
\text { interlobular tissue at a variable distance. (Yellow } \\
\text { arrows). Focal area of early hepato-cellular necrosis } \\
\text { (black arrow) is seen and represented by pyknotic } \\
\text { nuclei and deep eosinophilic cytoplasm, co-joined with } \\
\text { moderate hepato-cellular degenerative changes of } \\
\text { changeable degrees counting overcast swelling, } \\
\text { hydropic degeneration, vacuolations and signet-ring } \\
\text { fatty change cells( white arrow). Scattered multifocal } \\
\text { apoptosis of individual hepatocytes is seen (green } \\
\text { arrow). Some of the portal blood vessels (portal veins } \\
\text { and arteries) are moderately dilated (red arrows). Scale } \\
\text { bars 50 um, 25 um. }\end{array}$ \\
\hline
\end{tabular}




\section{Conceivable Effect of feeding Crackers Containing Peas and Tangerine Peels on Rats with diabetes induced by alloxan}

Hanan S. Shalaby and Hanan El-Sayed

Liver sections

\begin{tabular}{|c|c|}
\hline 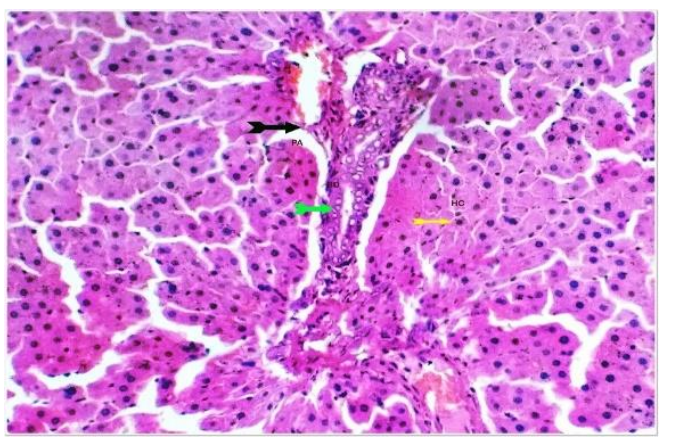 & 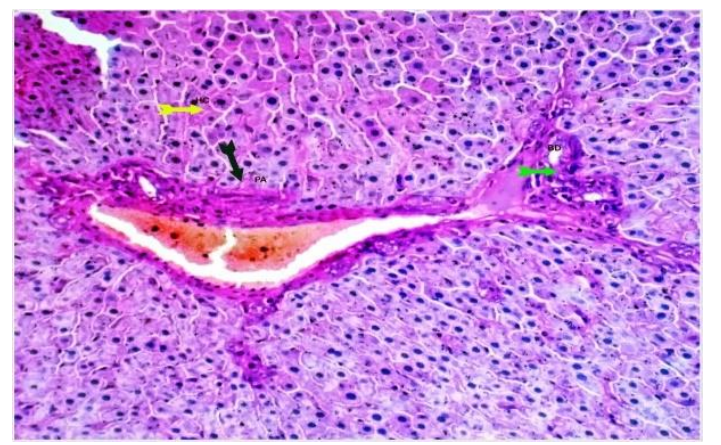 \\
\hline $\begin{array}{l}\text { Photo (2.c). Liver group fed on crackers without any } \\
\text { additives (G3) of rats showing mild to modest } \\
\text { overcrowding of the portal blood vessels, ( yellow } \\
\text { arrows), biliary hyperplasia, sometime associated with } \\
\text { fibroplasia(blue arrows ) near degenerative changes } \\
\text { in some hepatocytes mainly cloudy swelling and } \\
\text { hydropic degeneration( black arrow). A few apoptotic } \\
\text { ells are seen.( red arrows) . other parts of the hepatic } \\
\text { parenchyma are normal ( green arrow ). Scale bars } \\
\text { 50um, } 25 \text { um. }\end{array}$ & $\begin{array}{l}\text { Photo (2.d). Liver group fed on crackers } 10 \% \text { peas peels } \\
\text { (G4) of rats showing normal hepatocytes in mainly } \\
\text { fractions of the tissue, although a few hepatocytes shows } \\
\text { cloudy swelling and apoptotic changes (green and black } \\
\text { arrows). The portal triadesappears normal in most areas } \\
\text { of investigation with a minor vascular dilatations, and } \\
\text { biliary proliferation (yellow and blue arrows). The } \\
\text { hepatic sinusoids in some areas of the hepatic lobules } \\
\text { were mildly dilated and the Von kupffer's cells are } \\
\text { prominent (white arrow). Scale bars } 50 \mathrm{um,} 25 \mathrm{um.}\end{array}$ \\
\hline & -7 \\
\hline
\end{tabular}

Photo (2.e). Liver group fed on crackers $10 \%$ tangerine peels (G5) of rats showing apparently normal hepatic parenchyma and stroma by normal arrangement of hepatic lobules, hepatic cords, central veins, sinusoids and Von-Kuffer cells( yellow, blue and black arrows). Mild biliary proliferation is seen (green arrows) Scale bars 50 um, 25 um. 


\section{Conceivable Effect of feeding Crackers Containing Peas and Tangerine Peels on Rats with diabetes induced by alloxan}

Hanan S. Shalaby and Hanan El-Sayed

\section{Kidney sections}

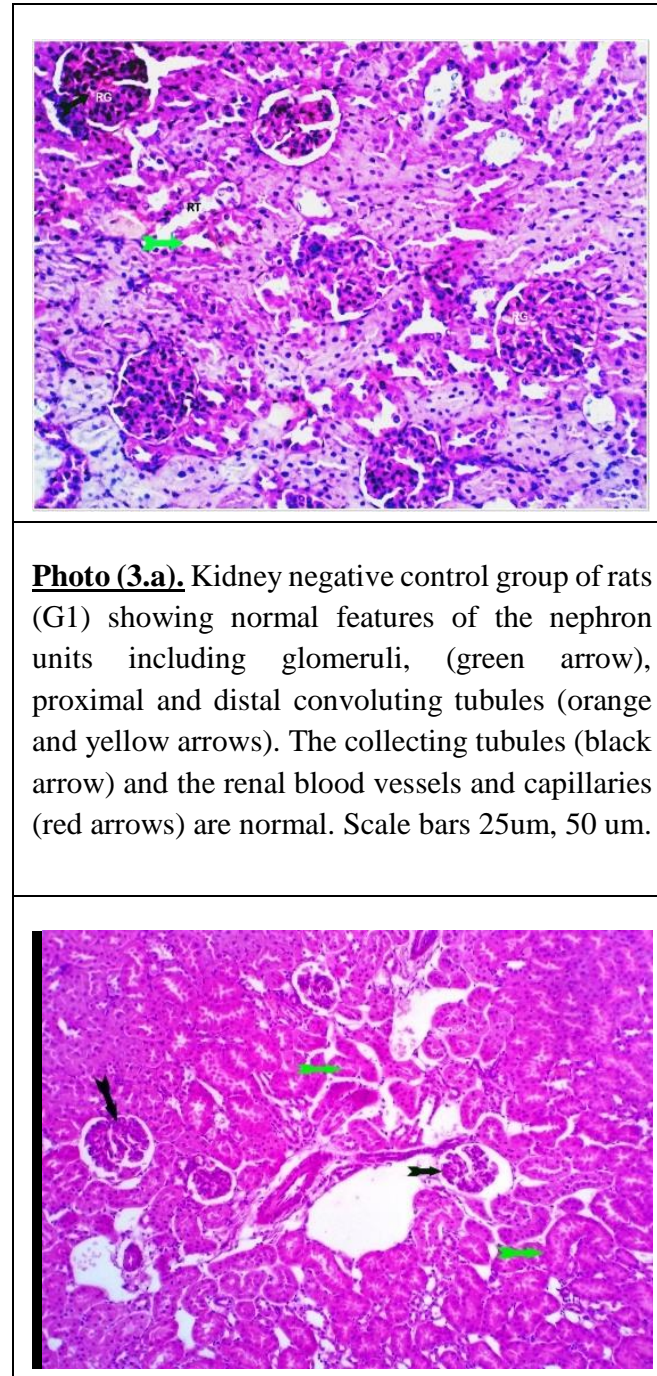

Photo (3.c). Kidney group fed on crackers without any additives (G3) of rats showing mild congestion of renal blood vessels sometimes with mild edematous changes (red arrow), degenerative and apoptotic changes in some tubular epithelia (green arrows). Some glomeruli shows shrinkage or lobulation of their capillary tufts. (yellow arrows). Normal renal tubules are also seen (blue arrows). Scale bars $50 \mathrm{um}, 25 \mathrm{um}$.

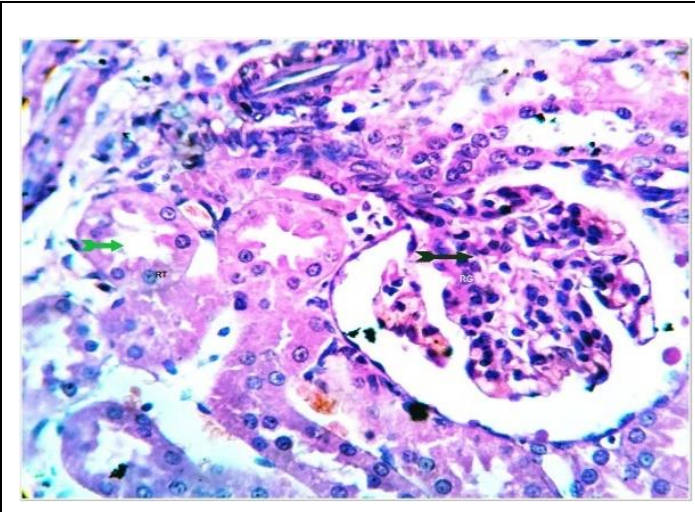

Photo (3.b). Kidney positive control group of rats showing variable degrees of degenerative changes including cloudy swelling, vacuolar and hydropic degeneration (green arrows). Perivascular edema and mild to moderate congestion of intertubular and glomerular blood vessels and capillaries are seen (yellow arrows). Moderate number of the glomeruli appears with shrinkage or lobulation of their capillary tufts. (Red arrow). Scale bars 50 um, 25 um

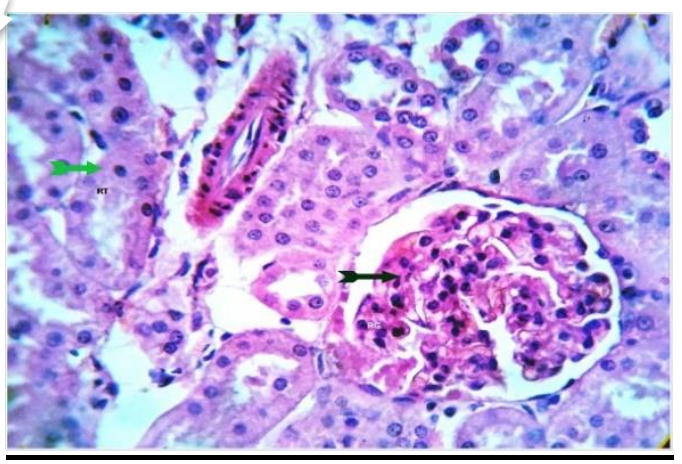

Photo (3.d). Kidney group fed on crackers $10 \%$ peas peels (G4) of rats mild congestion of renal blood vessels( black arrow), perivascular edema( green arrow) and degenerative modify (overcast swelling and hydropic degeneration ) in a few tubular epithelia( yellow arrow). A few glomeruli appears with shrinked or lobulated capillary tufts (blue arrows) and prominent Juxta glomerular apparatus (white arrow) .Scale bars 50 um, 25 um. 


\section{Kidney sections}

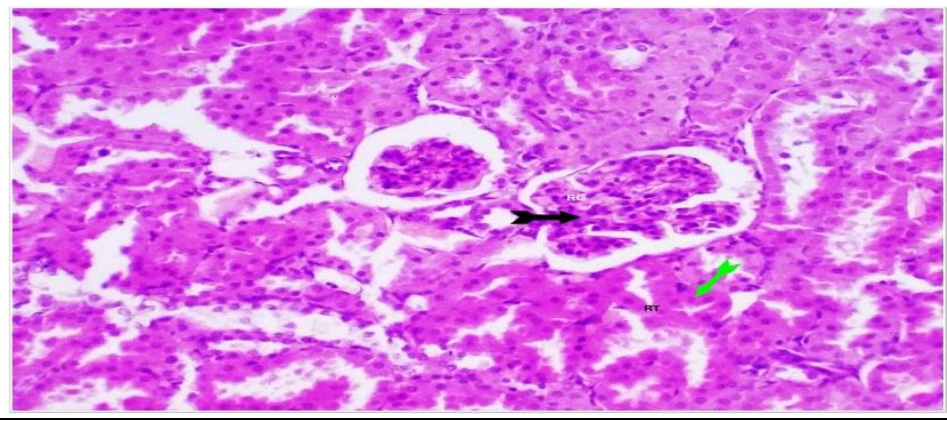

Photo (3.e). Kidney group fed on crackers $10 \%$ tangerine peels (G5) of rats showing normal histomorphology of nephron units with keeping features of normal glomeruli ( blue arrows)i, proximal and distal convoluted tubules beside loops of Henle( green arrows). Mild lobulation of the glomerular capillary tufts (blue arrows) and hydropic degeneration of a few tubules (yellow arrows) are seen. Scale bars 50 um, 25 um. 


\section{التأثير المحتمل للتغذيةٌّة بالمقرمشات المحتوبه على قشور البازلاء واليوسفي على الجرذان المصابة بمرض السكري المستحث: بالألوكسان

$$
\text { حنان سعيد شلبي وحنان السيد }
$$ \\ قسم علوم الاغذيه (شعبه الاقتصاد المنزلى الريفي ) كليه الزراعه جامعه الزقازيق مصر \\ الملخص العربي}

تعتبرقشور الخضر والفاكهه من الدصادر /الغنبه بالفيبولات والخواص المضاده

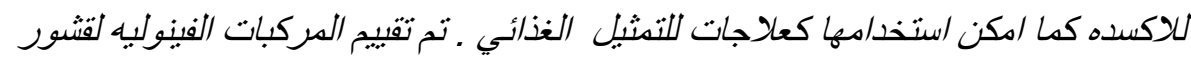

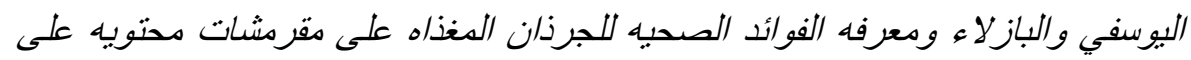

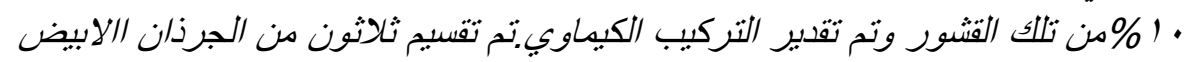
الاصحاء الذكور الى خدس مجدوعات (سته بكل مجموعه). المجموعه الاولى تم تغذيتها

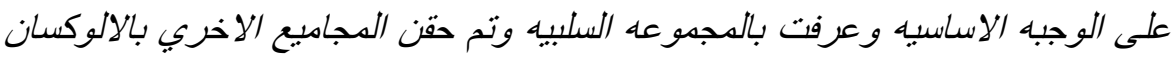

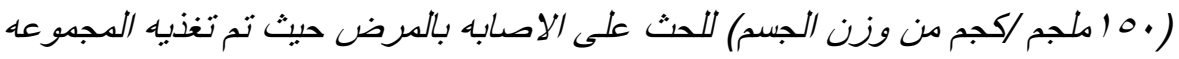

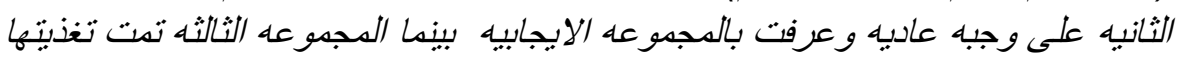

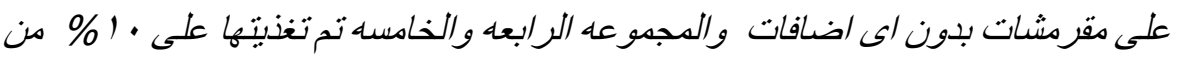

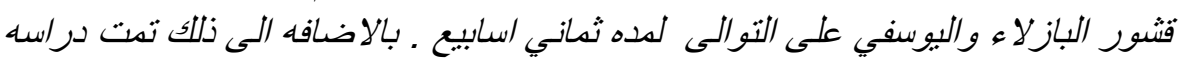

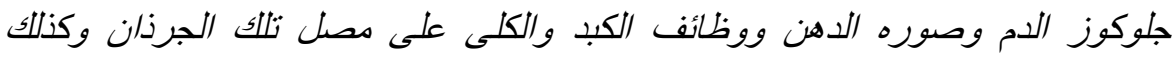

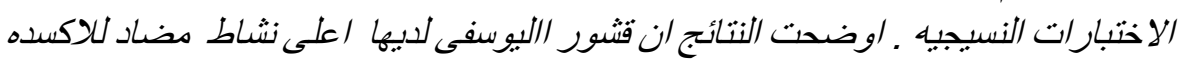

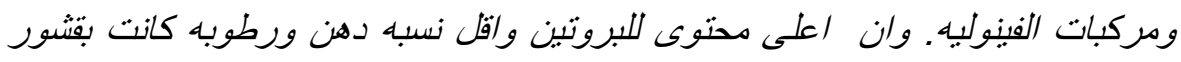

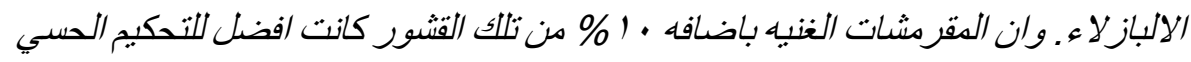

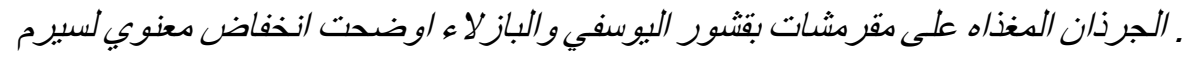

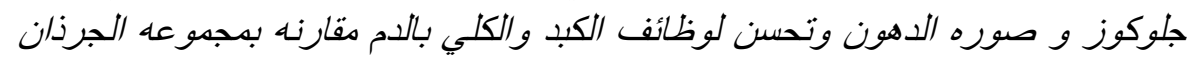

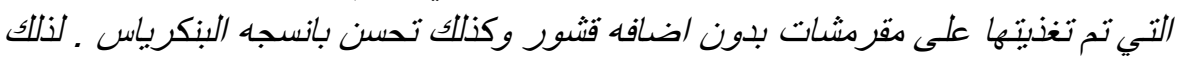

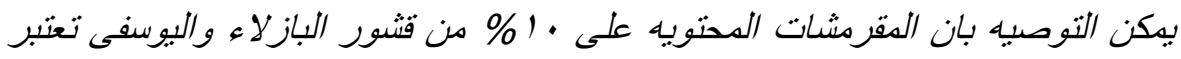

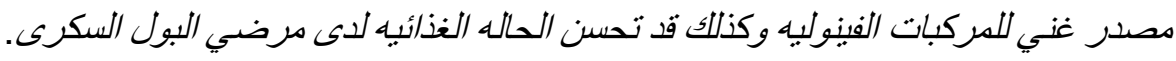
الكلمات المفتاحيه : المركبات الفبنوليه , وظائف الكبب والكلى , جرذان مرضي البول السكرى 